RESEARCH

\title{
Gremlin, noggin, chordin and follistatin differentially modulate BMP-induced suppression of androgen secretion by bovine ovarian theca cells
}

\author{
Claire Glister ${ }^{1}$, Sheena L Regan², Moafaq Samir ${ }^{1, \dagger}$ and Phil G Knight ${ }^{1}$ \\ 1School of Biological Sciences, Hopkins Building, University of Reading, Reading, UK \\ ${ }^{2} \mathrm{School}$ of Biomedical Sciences, Curtin University, Perth, Western Australia, Australia \\ Correspondence should be addressed to P G Knight: p.g.knight@reading.ac.uk \\ ${ }^{\dagger}(\mathrm{M}$ Samir is now at College of Veterinary Medicine, University of Wasit, Wasit, Iraq)
}

\begin{abstract}
Bone morphogenetic proteins (BMPs) are firmly implicated as intra-ovarian regulators of follicle function and steroidogenesis, but information is lacking regarding the regulation of BMP signalling by extracellular binding proteins co-expressed in the ovary. In this study, we compared the abilities of four BMP-binding proteins (gremlin, noggin, chordin, follistatin) to antagonize the action of four different BMPs (BMP2 BMP4, BMP6, BMP7) on $\mathrm{LH}$-induced androstenedione secretion by bovine theca cells in primary culture. Expression of the four BMP-binding proteins and BMPs investigated here has previously been documented in bovine follicles. All four BMPs suppressed androstenedione secretion by $>85 \%$. Co-treatment with gremlin antagonized BMP2- and, less potently, BMP4-induced suppression of androgen secretion but did not affect responses to BMP6 and BMP7. Noggin antagonized the effects of three BMPs (rank order: BMP4 > BMP2 > BMP7) but did not affect the response to BMP6. Follistatin partially reversed the suppressive effects of BMP6 on androgen secretion but did not affect BMP2, BMP4 and BMP7 action. Chordin had no effect on the response to any of the four BMPs. BMP6 treatment upregulated thecal expression of GREM1, NOG, CHRD and SMAD6 mRNA whilst inhibiting expression of the four BMPs. Taken together with previous work documenting the intra-ovarian expression of different BMPs, BMP-binding proteins and signalling receptors, these observations reinforce the conclusion that extracellular binding proteins selectively modulate BMP-dependent alterations in thecal steroidogenesis. As such they likely constitute an important regulatory component of this and other intra-ovarian actions of BMPs.
\end{abstract}

Journal of Molecular Endocrinology (2019) 62, 15-25

\section{Introduction}

Various ligands belonging to the TGF $\beta$ superfamily, including members of the bone morphogenetic protein (BMP) subfamily, are firmly implicated as intra-ovarian regulators of follicle development, steroidogenesis, cell proliferation/survival, ovulation and luteal function (Shimasaki et al. 2004, Knight \& Glister 2006, Regan et al.
Key Words
- female reproduction
- growth factors
- ovarian function
- follicles
- ovary 
2018). Different ovarian cell types (theca cells, granulosa cells, oocyte) exhibit selective expression of individual TGF $\beta$ superfamily ligands, signalling receptors, pseudoreceptors and secreted binding proteins consistent with operational autocrine/paracrine signalling pathways within and between different intrafollicular compartments. For example, activin, BMP2, BMP4, BMP6 and BMP7 have been shown to exert an anti-luteinization effect on granulosa cells (GC) by enhancing basal, FSH-induced and/or IGFinduced estradiol secretion whilst suppressing progesterone secretion (Otsuka et al. 2001b, Souza et al. 2002, Glister et al. 2004, Lee et al. 2004, Juengel et al. 2006). The same TGF $\beta$ superfamily ligands have been shown to attenuate basal and LH-induced androgen secretion by cultured theca cells (TC) suggesting a role in preventing a premature increase in androgen production by developing antral follicles (Hillier 1991, Wrathall \& Knight 1995, Glister et al. 2005, Campbell et al. 2006). As well as providing substrate for GC oestrogen synthesis, TC-derived androgens enhance GC FSH receptor expression and FSH-dependent follicle development (Rice et al. 2007, Sen et al. 2014).

BMPs and activins exert their effects on target cells in the ovary and elsewhere by forming hetero-oligomeric complexes with two types of signalling receptor (type 1 , type 2) on the cell surface. Type 1 receptors include BMPR1A (ALK3), ACVR1B (ALK4) and BMPR1B (ALK6); type 2 receptors include BMPR2, ACVR2A and ACVR2B) (Chen et al. 2004). At the extracellular level, access of activins/BMPs to signalling receptors on the cell surface can be modulated by a range of secreted binding proteins including gremlin, noggin, chordin and follistatin (Gazzerro \& Canalis 2006, Walsh et al. 2010, Mulloy \& Rider 2015) or by secreted antagonists such as inhibin (Wiater \& Vale 2003). At the intracellular level, additional regulatory mechanisms serve to enhance or attenuate BMP-activated signal transduction (Miyazono 2000, Canalis et al. 2003, Itoh \& ten Dijke 2007).

Despite their well-established role in the establishment of morphogen signalling gradients during embryonic and foetal development (Canalis et al. 2003, Chen et al. 2004, Walsh et al. 2010, Mulloy \& Rider 2015), within the context of intrafollicular BMP signalling, there have been relatively few studies to examine the functional significance of extracellular binding proteins other than follistatin (Xiao et al. 1990, Nakamura et al. 1992, Glister et al. 2004, 2015, Pierre et al. 2005). However, gremlin 1 and 2 have been shown to antagonize BMP4-induced inhibition of FSH-induced progesterone production by rat GC (Sudo et al. 2004) and to reverse BMP4-induced activation of primordial follicles in a rat ovary explant model (Nilsson et al. 2014). Gremlin 1 was also shown to block BMP4-induced prostaglandin secretion by mouse GC (Pangas et al. 2004) and to enhance androgen secretion by cultured bovine TC (Glister et al. 2005). The latter observation suggests neutralization of an endogenous ligand (BMP4?) that suppresses thecal androgen secretion in an autocrine/paracrine manner. Noggin was shown to reverse the suppressive effect of BMP2 and BMP4 on progesterone secretion by sheep GC (Pierre et al. 2004).

Previous reports have documented the spatiotemporal patterns of expression of a range of BMPs (Erickson \& Shimasaki 2003, Fatehi et al. 2005, Juengel et al. 2006, Glister et al. 2010), signalling receptors (Erickson \& Shimasaki 2003, Fatehi et al. 2005, Glister et al. 2010, Regan et al. 2016) and BMP-binding proteins (Pangas et al. 2004, Glister et al. 2011) during follicle development in several species including cattle. In bovine follicles, gremlin (GREM1), noggin (NOG), follistatin (FST) and chordin (CHRD) mRNA expression levels were much higher in the granulosal layer than in the theca interna layer (Glister et al. 2011) indicating they are the principal intrafollicular source of these binding proteins. Moreover, differential binding protein expression patterns in each cell type accompanied antral follicle development, suggesting regulated rather than constitutive expression and implying functional roles (Glister et al. 2011). For instance, GREM1 expression was maximal in GC of small antral follicles (1-2 mm) declining to a low level in GC of large (11-18 mm) oestrogen-active follicles. NOG expression was also lowest in GC of large oestrogen-active follicles whilst FST and CHRD expression was greatest in this follicle category (Glister et al. 2011).

Information is lacking regarding the potential regulation of BMP signalling by extracellular binding proteins co-expressed in the ovary, particularly with respect to regulation of follicular theca cell function. To test the hypothesis that extracellular binding proteins differentially regulate the actions of BMPs on TC, this study compared the relative abilities of four different extracellular binding proteins (gremlin, noggin, follistatin, chordin) to antagonise to suppressive action of four BMPs (BMP2, BMP4, BMP6, BMP7) on androgen secretion by bovine TC in primary culture. To explore additional autoregulatory mechanisms that may serve to limit BMP action, we also examined the effect of one of these BMPs (BMP6) on thecal expression of each of the above-mentioned BMPs and BMP-binding proteins, and also on expression of the inhibitory Smad, SMAD6. 


\section{Materials and methods}

\section{Bovine ovaries and theca cell culture}

Bovine theca interna cells (TCs) were isolated from the ovaries of randomly cycling cattle obtained from the slaughterhouse as described in detail elsewhere (Glister et al. 2005). Briefly, antral follicles (4-6 mm diameter) of healthy morphological appearance were hemisected and granulosa cell layers dislodged using a plastic inoculation loop. After vigorous shaking and washing (x3) to remove remaining adherent $\mathrm{GC}$, follicle halves were examined under the dissecting microscope. Theca interna layers were peeled away from the basement membrane and pooled theca interna layers from approximately 50 follicles were dissociated into single cells by incubating (30 min) with collagenase (type IV, $1 \mathrm{mg} / \mathrm{mL}$; Sigma Ltd., Poole, UK) and trypsin inhibitor $(0.1 \mathrm{mg} / \mathrm{mL}$; Sigma $)$ in a shaking water bath at $37^{\circ} \mathrm{C}$ (see (Glister et al. 2005) for further details). Cells were washed and counted using a hemocytometer and viability ( $>90 \%)$ assessed using trypan blue. The resultant theca interna cell preparations obtained using this method were judged to have $<5 \%$ contamination with GCs based on a previous RT-qPCR analysis of relative abundance of thecal (CYP17A1, INSL3) and granulosal (CYP19A1, FSHR) 'marker' transcripts (Glister et al. 2010). Moreover, oestradiol levels in TC-conditioned culture media were undetectable (data not shown).

For each experiment cells were seeded into 96-well tissue culture plates (Nunclon, Life Technologies Ltd, Paisley, UK) at 75,000 viable cells/well and cultured for 6 days $(144 \mathrm{~h})$ under defined serum-free conditions. For experiments in which RNA extraction was planned, cells were seeded into 24 -well tissue culture plates at 250,000 viable cells/well. The culture medium was McCoy's 5A modified medium supplemented with $1 \%(\mathrm{v} / \mathrm{v})$ antibiotic-antimycotic solution, $10 \mathrm{ng} / \mathrm{mL}$ bovine insulin, $2 \mathrm{mM}$ L-glutamine, $10 \mathrm{mM}$ HEPES, $5 \mu \mathrm{g} / \mathrm{mL}$ apo-transferrin, $5 \mathrm{ng} / \mathrm{mL}$ sodium selenite and $0.1 \%(\mathrm{w} / \mathrm{v})$ BSA (all purchased from Sigma UK Ltd). Cells were cultured without treatments for the first $48 \mathrm{~h}$. Medium was removed after 48 and $96 \mathrm{~h}$ and replaced with fresh medium containing treatments (see below). At the end of culture $(144 \mathrm{~h})$ conditioned media were stored at $-20^{\circ} \mathrm{C}$ for subsequent steroid immunoassays. Viable cell number at the end of culture was determined by neutral red dye uptake assay (Glister et al. 2001) to provide an assessment of cell proliferation/survival.

\section{Treatments}

Ovine LH (NIADDK oLH-S-16) was obtained from NHPP, Torrance, CA, USA. Recombinant human BMP2, BMP4, BMP6, BMP7, gremlin, noggin, follistatin-288 and recombinant mouse chordin were purchased from R\&D Systems. Treatments were prepared in Hank's balanced salt solution containing $0.1 \%(\mathrm{w} / \mathrm{v})$ BSA and sterile stock solutions prepared using $0.2 \mu \mathrm{m}$ membrane filters before further dilution in sterile culture medium. The concentrations of LH (150 pg/mL) and BMP2, BMP4, BMP6 and BMP7 $(10 \mathrm{ng} / \mathrm{mL})$ selected for these experiments were considered optimal based on their modulatory effects on androstenedione secretion observed in our previous studies on bovine TC (Glister et al. 2005, 2010, 2011). Each BMP-binding protein was tested at three different concentrations $(50,250,1250 \mathrm{ng} / \mathrm{mL})$ for its ability to antagonize BMP-induced suppression of androstenedione secretion by LH-stimulated cells. Co-treatments were prepared 30-40 min before addition to cells by mixing appropriate concentrations of BMP and BMP-binding protein. A further experiment examined the effect of 24, 48 and $96 \mathrm{~h}$ exposure to BMP6 (10 ng/mL) alone on the relative abundance of CHRD, GREM1, NOG, FST, BMP2, BMP4, BMP6, BMP7 and SMAD6 mRNA.

\section{Steroid assays}

Concentrations of androstenedione in TC-conditioned media were determined by ELISA as reported previously (Glister et al. 2013). The detection limit was $0.1 \mathrm{ng} / \mathrm{mL}$ and average intra- and inter-assay CVs were 7 and $10 \%$ respectively. Progesterone concentrations were determined by ELISA (Satchell et al. 2013). The detection limit was $0.1 \mathrm{ng} / \mathrm{mL}$ and average intra- and inter-assay CVs were 8 and $11 \%$ respectively.

\section{Real-time PCR analysis}

Total RNA was isolated using tri-reagent as described previously (Glister et al. 2010). cDNA was synthesized from $1 \mu \mathrm{g}$ of RNA using the $\mathrm{AB}$ High-Capacity cDNA synthesis kit (Thermo Fisher Scientific; used according to manufacturer's protocol) with random hexamers. PCR primers (Table 1) were designed using the online primer designing tool 'Primer-BLAST' (http://www.ncbi.nlm.nih. gov/tools/primer-blast) with BLAST specificity checking against all known bovine (Bos taurus) transcripts to exclude potential amplification of off-target sequences. PCR assays were carried out in a volume of $14 \mu \mathrm{L}$ containing $5 \mu \mathrm{L}$ cDNA 


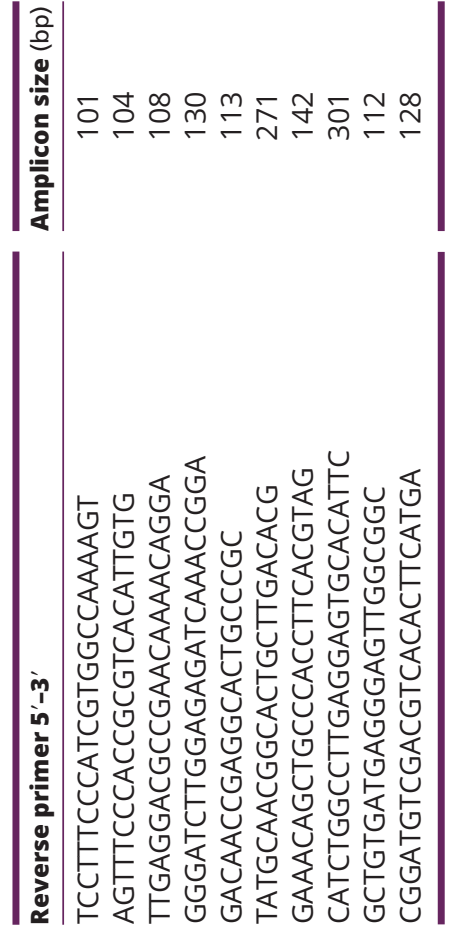

(3)

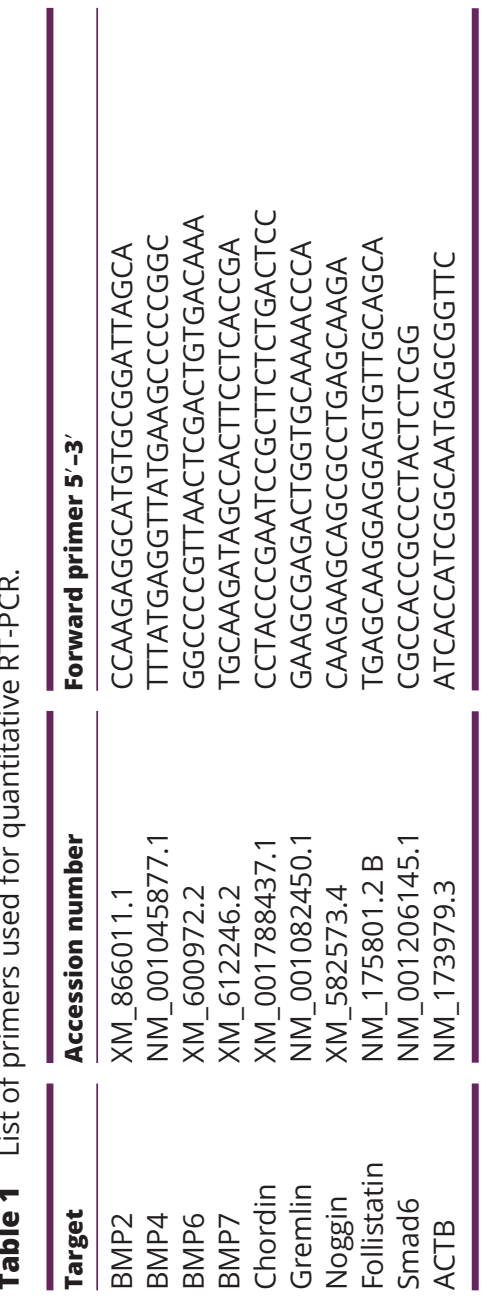

template, $1 \mu \mathrm{L}$ each forward and reverse primers (final concentration $0.36 \mu \mathrm{M}$ ) and $7 \mu \mathrm{L}$ QuantiTect SYBR Green QPCR 2x Master Mix (Qiagen). Samples were processed on a StepOne Plus thermal cycler (Applied Biosystems) with cycling conditions: $15 \mathrm{~min}$ at $95^{\circ} \mathrm{C}$ (one cycle only) followed by $15 \mathrm{~s}$ at $95^{\circ} \mathrm{C}$ and $1 \mathrm{~min}$ at $60^{\circ} \mathrm{C}$ for 40 cycles. The $\Delta \Delta$ Ct method (Livak \& Schmittgen 2001) was used to compare the relative abundance of each mRNA transcript. $\mathrm{Ct}$ values for each transcript in a given sample were first normalized to the corresponding $\beta$-actin (ACTB) Ct value (i.e. $\triangle \mathrm{Ct}$ value). $A C T B$ expression level was uniform across experimental treatments. $\Delta \mathrm{Ct}$ values for each transcript in a given sample were then normalized to the corresponding $\Delta \mathrm{Ct}$ value for that transcript untreated control (time zero) samples. For graphical presentation $\Delta \Delta \mathrm{Ct}$ values were converted to fold-differences using the formula: folddifference $=2^{(-\Delta \Delta \mathrm{Ct})}$.

\section{Statistical analysis}

Hormone secretion data were log-transformed prior to statistical analysis to reduce heterogeneity of variance. Effects of treatments (LH, BMP, BMP-binding protein) on hormone secretion (for final $96-144 \mathrm{~h}$ period of culture) and viable cell number at the end of culture were evaluated by one- and two-way ANOVA. Post hoc pairwise comparisons were made using Fisher's PLSD test. Gene expression results were analysed by one-way ANOVA as $\Delta \Delta \mathrm{Ct}$ values before conversion to fold-differences. Results are presented as arithmetic means \pm s.E.M. based on 3-4 independent culture experiments using different batches of TCs.

\section{Results}

Treatment of cells with $\mathrm{LH}$ alone elicited a $\sim$ four-fold increase in androstenedione secretion $(P<0.001)$ but did not affect progesterone secretion or viable cell number at the end of culture (144h) (Fig. 1A). Treatment of cells with BMP2, BMP4, BMP6 and BMP7 promoted a marked suppression of LH-stimulated androstenedione secretion $(>85 \% ; P<0.001)$ whilst promoting a $\sim 2$-fold increase in progesterone secretion $(P<0.001)$. Viable cell number at the end of culture was not affected by BMP treatment (Fig. 1B).

Figure 2 shows the effects of the four BMPs alone and in combination with gremlin. Treatment of cells with BMP2, BMP4, BMP6 or BMP7 promoted a marked ( $>6$-fold) suppression of androstenedione secretion $(P<0.0001)$ accompanied by a modest increase in progesterone 
A
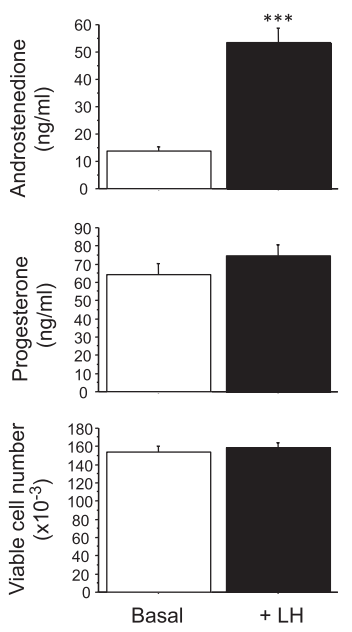

Effects of (A) LH and (B) BMP2, BMP4, BMP6 and BMP7 on secretion of androstenedione and progesterone by bovine theca interna cells and on viable cell number at the end of culture. In (B) cells were cultured in the presence of LH. Values are means and bars indicate SEM $(n=3$ independent cultures). ${ }^{*} * P<0.001$ vs control.

secretion $(P<0.001)$. Treatment with gremlin alone raised mean androstenedione secretion $\sim 2$-fold but the effect was not significant. Two-way ANOVA showed a highly significant effect of BMP type and gremlin dose-level on androstenedione secretion, as well as a BMP $\times$ gremlin dose-level interaction. Co-treatment with $250 \mathrm{ng} / \mathrm{mL}$ gremlin reversed the suppression in androstenedione secretion induced by BMP2 $(P<0.05)$ whilst a higher gremlin concentration $(1250 \mathrm{ng} / \mathrm{mL})$ was required to reverse the suppressive effect of BMP4 $(P<0.05)$. At the dose levels tested gremlin did not reverse the effects of BMP6 or BMP7. Regarding progesterone secretion, twoway ANOVA showed a non-significant $B M P \times$ gremlin interaction $(P=0.09)$.

With respect to noggin treatment (Fig. 3), two-way ANOVA indicated a highly significant effect of BMP type $(P<0.0001)$ and noggin dose level $(P<0.0001)$ on androstenedione secretion, as well as a $\mathrm{BMP} \times$ noggin dose-level interaction $(P<0.0001)$. Closer examination of the results showed that treatment with noggin alone had no effect on androstenedione secretion but effectively reversed the suppressive actions of BMP2, BMP4 and BMP7. The lowest concentrations of noggin required to promote a significant $(P<0.05)$ reversal of BMP-induced suppression of androstenedione secretion were $50 \mathrm{ng} / \mathrm{mL}$
A $\bar{\varepsilon}$

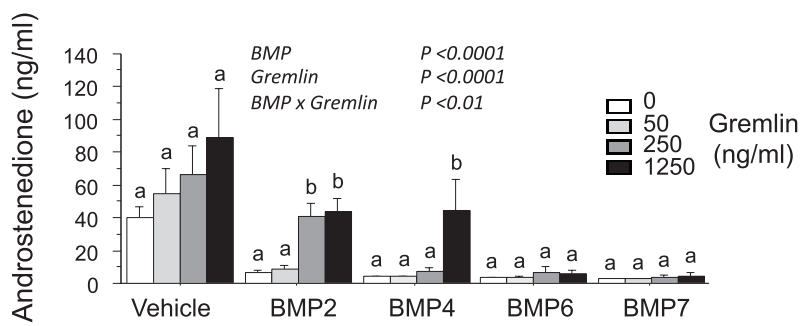

$\mathrm{B}$

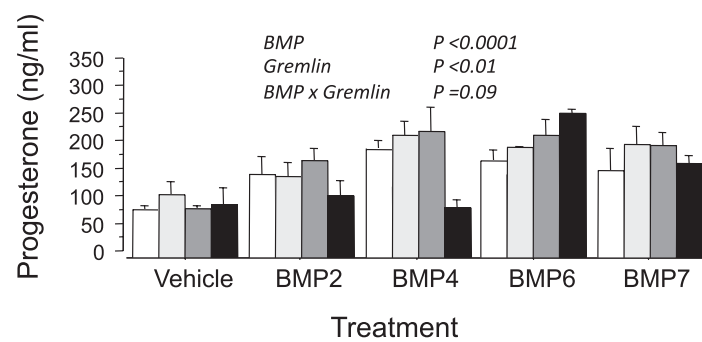

Figure 2

Effects of gremlin on secretion of (A) androstenedione and (B) progesterone by bovine theca interna cells treated with BMP2, BMP4, BMP6 or BMP7 under LH-stimulated conditions. Values are means and bars indicate S.E.M. ( $n=3$ independent experiments). Results of 2-way ANOVA are indicated. Within each BMP treatment group, means without a common letter are significantly $(P<0.05)$ different.

for BMP4, $250 \mathrm{ng} / \mathrm{mL}$ for BMP2 and $1250 \mathrm{ng} / \mathrm{mL}$ for BMP7. At the dose-levels tested noggin did not reverse the effects of BMP6. Regarding progesterone secretion, two-way ANOVA showed a non-significant BMP $\times$ noggin interaction $(P=0.02)$.

\section{A}

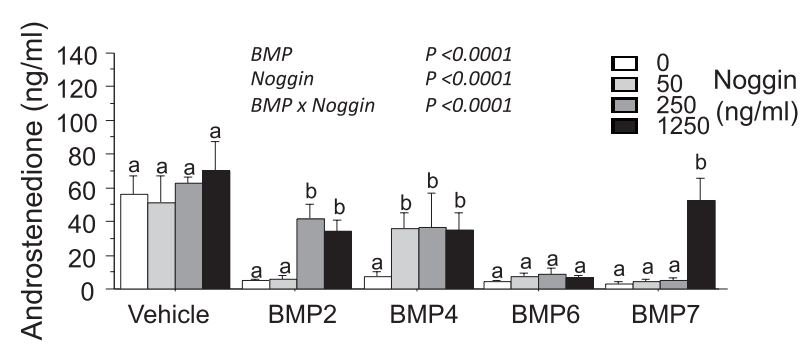

$\mathrm{B}$

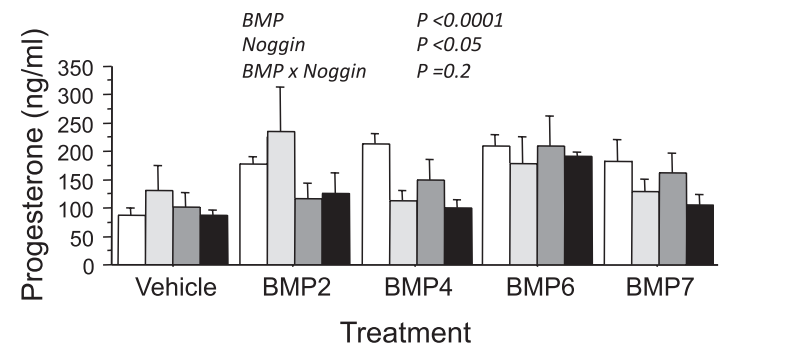

Figure 3

Effects of noggin on secretion of (A) androstenedione and (B) progesterone by bovine theca interna cells treated with BMP2, BMP4, BMP6 or BMP7 under LH-stimulated conditions. Values are means and bars indicate S.E.M. ( $n=3$ independent experiments). Results of 2-way ANOVA are indicated. Within each BMP treatment group, means without a common letter are significantly $(P<0.05)$ different. 


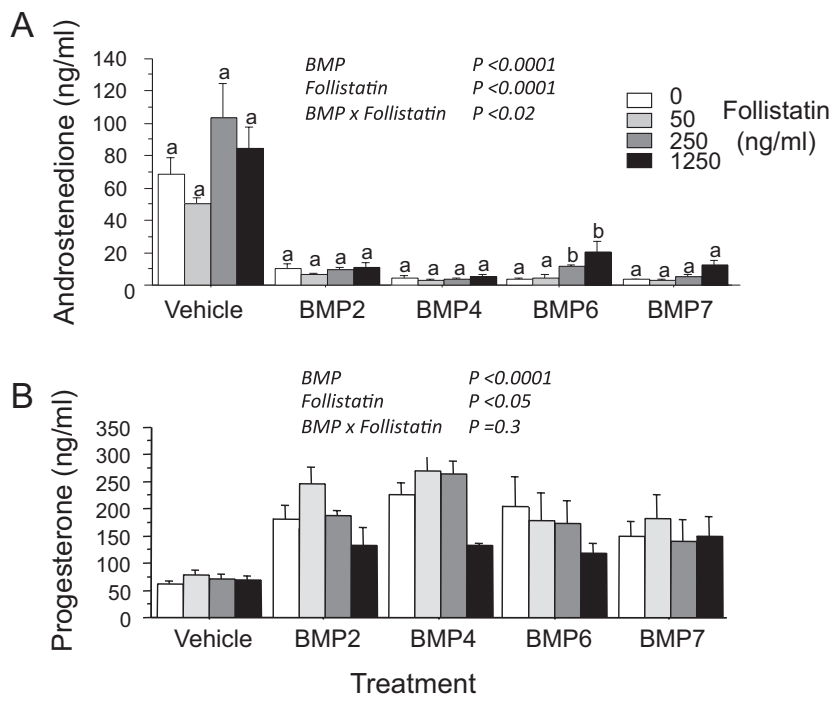

Figure 4

Effects of follistatin on secretion of (A) androstenedione and (B) progesterone by bovine theca interna cells treated with BMP2, BMP4, BMP6 or BMP7 under LH-stimulated conditions. Values are means and bars indicate S.E.M. ( $n=3$ independent experiments). Results of 2-way ANOVA are indicated. Within each BMP treatment group, means without a common letter are significantly $(P<0.05)$ different.

Figure 4 shows the effects of BMPs alone and in combination with follistatin. Again, there was a highly significant effect of BMP type $(P<0.0001)$ and follistatin dose-level $(P<0.0001)$ on androstenedione secretion, as well as a BMP $\times$ follistatin dose-level interaction $(P<0.02)$. Treatment with follistatin alone had no effect on basal androstenedione secretion but androstenedione secretion in the presence of BMP6 was increased $(P<0.05)$ by the addition of follistatin, indicating a partial reversal of the response to BMP6. Follistatin did not affect androstenedione secretion in the presence of BMP2, BMP4 or BMP7. With respect to progesterone secretion, twoway ANOVA showed a non-significant $\mathrm{BMP} \times$ follistatin interaction $(P=0.3)$.

As shown in Fig. 5 chordin had no effect on basal androstenedione secretion and did not reverse the suppressive effects of BMP2, BMP4, BMP6 or BMP7 on androstenedione secretion. Likewise chordin did not affect progesterone secretion and two-way ANOVA showed a non-significant $\mathrm{BMP} \times$ chordin interaction $(P=0.72)$.

Figure 6 shows that treatment of cells with BMP6 for $96 \mathrm{~h}$ promoted a marked, time-dependent increase in relative abundance of mRNA for GREM1 ( 25-fold; $P<0.001)$, NOG ( 25-fold; $P<0.001)$ and CHRD ( 10-fold; $P<0.001)$ but did not affect FST mRNA expression. Only marginal increases in binding protein expression levels were observed after shorter exposure periods (24 and
$48 \mathrm{~h})$. Treatment with BMP6 promoted a time-dependent reduction in $B M P 2, B M P 4$ and BMP6 mRNA transcript abundance $(P<0.001)$. BMP7 transcript abundance was also reduced at 24 and $48 \mathrm{~h}$ but not at $96 \mathrm{~h}$. In addition, BMP6 treatment promoted a marked $(\sim 45$-fold; $P<0.001)$ and time-dependent increase in SMAD6 transcript abundance.

\section{Discussion}

The present study sought to clarify the functional significance of potential interactions between different BMPs and BMP-binding proteins at the intrafollicular level. Since ovarian androgens play key roles in follicle development and function (Hillier 1987, Rice et al. 2007, Sen et al. 2014), we used a bovine primary TC culture model as a bioassay to evaluate, in a combinatorial manner, the abilities of four different binding proteins to counteract the inhibitory action of four different BMPs on androgen secretion. Progesterone secretion was also evaluated but since BMPs only elicit a modest change in progesterone secretion, this provided a much less robust end-point for comparing relative bio-potencies of the different binding proteins. Each of the binding proteins (CHRD, GREM1, NOG, FST) and BMPs (BMP2, BMP4, BMP6, $B M P 7)$ selected for the study has been shown previously
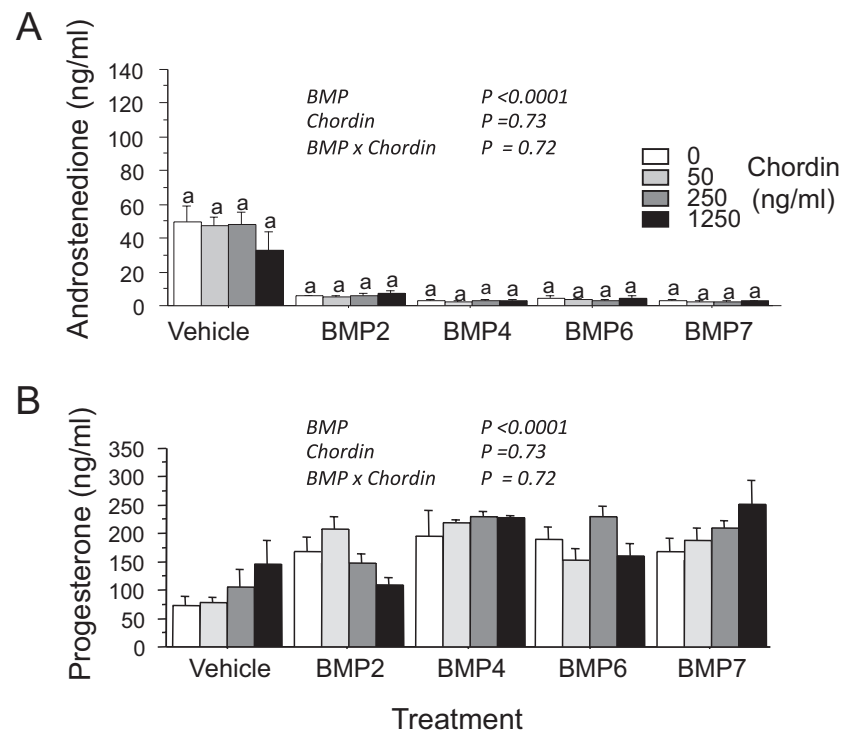

\section{Figure 5}

Effects of chordin on secretion of $(A)$ androstenedione and $(B)$ progesterone by bovine theca interna cells treated with BMP2, BMP4, BMP6 or BMP7 under LH-stimulated conditions. Values are means and bars indicate S.E.M. ( $n=3$ independent experiments). Results of 2-way ANOVA are indicated. Within each BMP treatment group, means without a common letter are significantly $(P<0.05)$ different. 

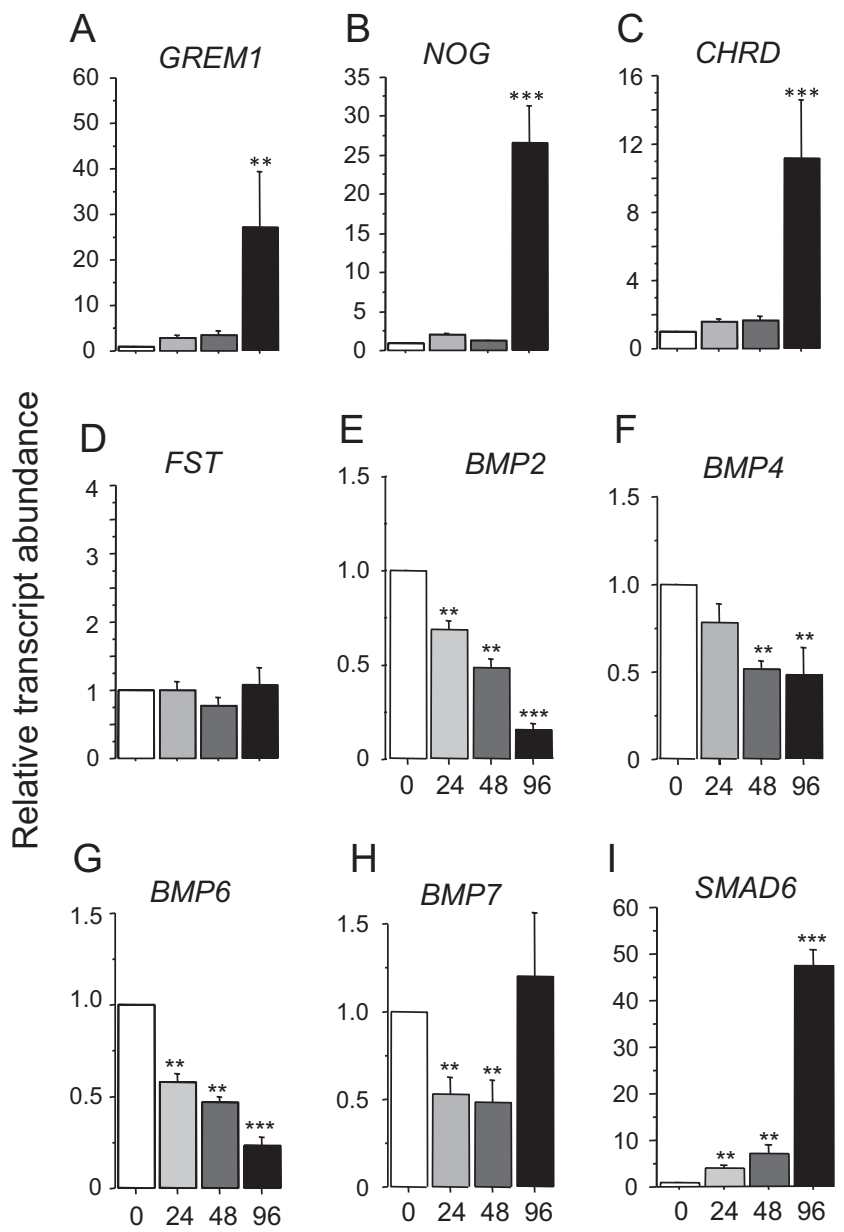

BMP6 treatment duration $(\mathrm{h})$

\section{Figure 6}

Time-dependent effect of BMP6 treatment on relative abundance of transcripts for (A) GREM1, (B) CHRD, (C) NOG, (D) FST, (E) BMP2, (F) BMP4, (G) $B M P 6$, (H) BMP7 and (I) SMAD6 in cultured bovine theca interna cells. Values are means and bars indicate S.E.M. ( $n=4$ independent experiments). ${ }^{*} P<0.05,{ }^{*} P<0.01,{ }^{*} * * P<0.001$ vs control.

to be expressed within bovine antral follicles in a cell-type and follicle stage-dependent manner (Glister et al. 2010, 2011). As anticipated from earlier studies (Glister et al. 2005,2013 ) all four BMPs elicited a robust suppression of thecal androgen secretion. Moreover, evidence supporting differential effects of binding proteins was obtained, consistent with selective modulation of autocrine/ paracrine BMP signalling in the ovarian follicle. Since GC, rather than TC, appear to be the predominant source of chordin, gremlin, noggin and follistatin in bovine antral follicles (Glister et al. 2011), it is likely that GC-derived binding proteins have a key role in regulating access of BMPs to their signalling receptors on TC, regardless of whether the BMPs are secreted by TC, GC or oocyte.
In this context, bovine $\mathrm{GC}$ were found to express high levels of BMP2 mRNA and protein whilst TC express higher levels of BMP4, BMP6 and BMP7 mRNA (Glister et al. 2010). BMP6 immunoreactivity was also detected in bovine oocytes and cultured GC whilst BMP4 and BMP7 immunoreactivity was more prevalent in cultured TC (Glister et al. 2004).

The present results show that gremlin and noggin were the most effective antagonists of BMP2-induced suppression of thecal androgen secretion, whilst follistatin and chordin had no effect. Previous studies have shown that gremlin reverses BMP2-induced suppression of progesterone secretion by rat GC (Sudo et al. 2004) and that noggin, but not follistatin, reverses the BMP2-induced suppression of progesterone secretion by sheep GC (Pierre et al. 2005). Noggin was also shown to reverse BMP2induced suppression of FSHR expression and progesterone production by hen GC (Haugen \& Johnson 2010). As mentioned above BMPs had little effect on progesterone secretion in our bovine TC model and so direct comparison with studies on granulosa cell progesterone production is difficult. To our knowledge, there are no reports from other groups examining effects of BMP-BMP-binding protein interactions on thecal androgen production in any species. In the bovine ovary BMP2, gremlin and noggin are predominantly of GC origin and showed their lowest expression levels in large oestrogen-active follicles (Glister et al. 2010, 2011), in contrast to follistatin and chordin which showed maximal expression in this follicle category (Glister et al. 2011). This leads to speculation that low BMP2 may contribute to the increased output of thecal androgen required for heightened oestrogen synthesis by the dominant oestrogen-active follicle.

Our data showed that noggin was the most potent antagonist of BMP4-induced suppression of thecal androgen secretion whilst gremlin was only effective at a 25 -fold higher concentration and follistatin and chordin had no effect. Previously, noggin was found to reverse BMP-4-induced inhibition of progesterone secretion by sheep GC whilst follistatin was without effect (Pierre et al. 2005). Noggin has also been shown to be a potent antagonist of BMP4 action on other non-endocrine cell types (Zimmerman et al. 1996, Canalis et al. 2003). As mentioned above BMP4 is predominantly expressed by TC and so the implication for intrafollicular signalling is that GC-derived noggin may diffuse through the basement membrane to modulate the autocrine/paracrine action of BMP4 on TC and thus contribute to the regulation of androgen output. Given the previous observation 
(Glister et al. 2011) that GC NOG expression is minimal in large oestrogen-active follicles, this would imply reduced antagonism of thecal BMP4 signalling at this follicle stage. Interestingly, NOG expression by cultured GC was inhibited by IGF analogue treatment perhaps accounting for low expression in large oestrogen-active follicles (Glister et al. 2005).

In contrast to NOG, FST expression is maximal in GC of large oestrogen-active bovine follicles (Glister et al. 2011) and is upregulated by both FSH and IGF1 in cultured GC (Glister et al. 2001, 2011). As well as binding to activin with high affinity (Nakamura et al. 1992), follistatin also binds with lower affinity to other TGF $\beta$ family members including BMP4, BMP6 and BMP7 (Glister et al. 2004), BMP-15 (Otsuka et al. 2001a) and myostatin (Amthor et al. 2004). Moreover, follistatin was shown to reverse BMP4- and BMP6-induced increases in phosphoSmad1 accumulation in bovine GC, but did not affect the response to BMP7 (Glister et al. 2004). Despite these previous findings, in this study follistatin only promoted a weak and partial reversal of BMP6-induced suppression of thecal androgen and did not affect the response to BMP2, BMP4 or BMP7. Similarly, follistatin did not antagonise the suppressive action of BMP2 or BMP4 on progesterone secretion by sheep GC but had a slight modulatory effect on the response to BMP6 (Pierre et al. 2005). As such, it seems questionable whether follistatin, primarily of GC origin, exerts a significant modulatory effect on intrafollicular BMP2, BMP4, BMP6 and BMP7 signalling although further investigation is needed to clarify this issue.

As observed for follistatin, GCs of large oestrogenactive bovine follicles were found to express the highest level of CHRD mRNA (Glister et al. 2011). However, in contrast to follistatin, expression of CHRD by cultured GC was not modulated by either FSH or IGF1 (Glister et al. 2011). Furthermore, in this study we found no modulatory effects of chordin on the TC response to any of the four BMPs examined. Whilst we are not aware of any other studies involving ovarian cells, chordin has been shown to bind to and antagonise the effects of several BMPs including BMP2, BMP4 and BMP7 on various development events including early dorsal patterning in chick and mouse (Piccolo et al. 1997, Gazzerro \& Canalis 2006). The lack of effect we observed was therefore unexpected, given the reported biological activity of the recombinant binding protein as stated by the suppliers. Since cleavage by the metalloproteinase, mammalian (m-) tolloid (aka BMP1), renders chordin unable to antagonize BMP activity (Piccolo et al. 1997, Ge \& Greenspan 2006), it is tentatively suggested that m-tolloid produced by the cultured TC could account for the lack of effect of chordin. In this regard, co-expression of BMP1, CHRD and BMP4 mRNA has been reported in sheep ovarian follicles (CantyLaird et al. 2010). Whilst m-tolloid immunoreactivity was mainly localised in the granulosa layer it was also evident in the theca layer of sheep antral follicles, lending some support to this possibility.

In a further experiment to explore other potential regulatory mechanisms governing intrafollicular BMP signalling, we examined the ability of one of the BMPs (BMP6) to modulate thecal expression of each of the four BMP-binding proteins and BMPs, as well as expression of the inhibitory Smad, SMAD6. Despite the failure of gremlin, noggin and chordin to antagonise the suppressive effect of BMP6 on thecal androgen secretion, BMP6 treatment was found to upregulate thecal expression of these three binding proteins in a time-dependent manner. This is consistent with previous findings (Glister et al. 2011) and suggests an additional autoregulatory feedback loop at the target cell level to restrict or attenuate signalling by other intrafollicular BMPs, to which the cells are exposed. BMPinduced upregulation of BMP-binding protein expression has been observed in other model systems. For example, Grem 1 expression by mouse GC (Pangas et al. 2004) and rat osteoblasts (Pereira et al. 2000a) was upregulated by BMP2 and BMP4. Likewise, Nog expression by osteoblasts was upregulated by BMP2, BMP4 and BMP6 (Gazzerro et al. 1998).

The finding that BMP6 downregulated its own mRNA expression, as well as expression of BMP2, BMP4 and $B M P 7$, suggests a direct ligand-dependent autoregulatory negative feedback effect operating in ovarian TCs. Similar effects have been reported for BMP4 and BMP2, which were both found to downregulate their own expression by cultured osteoblasts (Pereira et al. 2000b).

Inhibitory Smads (SMAD6, SMAD7) attenuate TGF $\beta$ family signalling by blocking interaction of type 1 receptors with receptor-regulated (R) Smads and by preventing the association of R-Smads with co-Smad (SMAD4) (Miyazono 2000, Itoh \& ten Dijke 2007). Since SMAD6 preferentially inhibits Smad signalling initiated by BMPs (Miyazono 2000), our finding of a marked, BMP6induced upregulation of SMAD6 expression provides evidence for a further intracellular negative feedback loop operating at the theca cell level to limit the duration and/or intensity of BMP signalling, akin to that observed in other cell types including lung cancer cell lines and chondrocytes (Afrakhte et al. 1998, Li et al. 2003). 
In conclusion, these findings underscore the complexity of the intra-ovarian BMP system comprising multiple ligands, extracellular binding proteins and signalling receptors. Thecal androgen production is negatively regulated by locally produced BMPs, the actions of which are modulated by various negative feedback loops. It remains a daunting challenge to evaluate the functional significance of individual BMPs, against a backdrop of multiple interacting autocrine and/ or paracrine pathways some of which may be redundant whilst others may play essential physiological roles to regulate different aspects of follicle function. Although suitable assays for BMPs and BMP-binding proteins (other than follistatin) are currently lacking, future studies to determine their respective intrafollicular concentrations would be a useful step towards defining their relative physiological significance.

\section{Declaration of interest}

The authors declare that there is no conflict of interest that could be perceived as prejudicing the impartiality of the research reported.

\section{Funding}

This work was supported by the Biotechnology and Biological Sciences Research Council (award BB/M001369/1 and BB/G017174/1 to P G K).

\section{Acknowledgements}

The authors thank D Butlin and A D Simmonds for technical assistance. The authors declare that there is no conflict of interest that could be perceived as prejudicing the impartiality of this scientific work.

\section{References}

Afrakhte M, Moren A, Jossan S, Itoh S, Sampath K, Westermark B, Heldin CH, Heldin NE \& ten Dijke P 1998 Induction of inhibitory Smad6 and Smad7 mRNA by TGF-beta family members. Biochemical and Biophysical Research Communications 249 505-511. (https://doi. org/10.1006/bbrc.1998.9170)

Amthor H, Nicholas G, McKinnell I, Kemp CF, Sharma M, Kambadur R \& Patel K 2004 Follistatin complexes Myostatin and antagonises Myostatin-mediated inhibition of myogenesis. Developmental Biology 270 19-30. (https://doi.org/10.1016/j.ydbio.2004.01.046)

Campbell BK, Souza CJ, Skinner AJ, Webb R \& Baird DT 2006 Enhanced response of granulosa and theca cells from sheep carriers of the FecB mutation in vitro to gonadotropins and bone morphogenic protein-2, -4, and -6. Endocrinology 147 1608-1620. (https://doi. org/10.1210/en.2005-0604)

Canalis E, Economides AN \& Gazzerro E 2003 Bone morphogenetic proteins, their antagonists, and the skeleton. Endocrine Reviews $\mathbf{2 4}$ 218-235. (https://doi.org/10.1210/er.2002-0023)
Canty-Laird E, Carre GA, Mandon-Pepin B, Kadler KE \& Fabre S 2010 First evidence of bone morphogenetic protein 1 expression and activity in sheep ovarian follicles. Biology of Reproduction 83 138-146. (https://doi.org/10.1095/biolreprod.109.082115)

Chen D, Zhao M, Harris SE \& Mi Z 2004 Signal transduction and biological functions of bone morphogenetic proteins. Frontiers in Bioscience 9 349-358. (https://doi.org/10.2741/1090)

Erickson GF \& Shimasaki S 2003 The spatiotemporal expression pattern of the bone morphogenetic protein family in rat ovary cell types during the estrous cycle. Reproductive Biology and Endocrinology 19. (https://doi.org/10.1186/1477-7827-1-9)

Fatehi AN, van den Hurk R, Colenbrander B, Daemen AJ, van Tol HT, Monteiro RM, Roelen BA \& Bevers MM 2005 Expression of bone morphogenetic protein2 (BMP2), BMP4 and BMP receptors in the bovine ovary but absence of effects of BMP2 and BMP4 during IVM on bovine oocyte nuclear maturation and subsequent embryo development. Theriogenology 63 872-889. (https://doi.org/10.1016/j. theriogenology.2004.05.013)

Gazzerro E \& Canalis E 2006 Bone morphogenetic proteins and their antagonists. Reviews in Endocrine and Metabolic Disorders 7 51-65. (https://doi.org/10.1007/s11154-006-9000-6)

Gazzerro E, Gangji V \& Canalis E 1998 Bone morphogenetic proteins induce the expression of noggin, which limits their activity in cultured rat osteoblasts. Journal of Clinical Investigation $\mathbf{1 0 2}$ 2106-2114. (https://doi.org/10.1172/JCI3459)

Ge G \& Greenspan DS 2006 Developmental roles of the BMP1/TLD metalloproteinases. Birth Defects Research Part C: Embryo Today $\mathbf{7 8}$ 47-68. (https://doi.org/10.1002/bdrc.20060)

Glister C, Tannetta DS, Groome NP \& Knight PG 2001 Interactions between follicle-stimulating hormone and growth factors in modulating secretion of steroids and inhibin-related peptides by nonluteinized bovine granulosa cells. Biology of Reproduction 65 1020-1028. (https://doi.org/10.1095/biolreprod 65.4.1020)

Glister C, Kemp CF \& Knight PG 2004 Bone morphogenetic protein (BMP) ligands and receptors in bovine ovarian follicle cells: actions of BMP-4, -6 and -7 on granulosa cells and differential modulation of Smad-1 phosphorylation by follistatin. Reproduction 127 239-254. (https://doi.org/10.1530/rep.1.00090)

Glister C, Richards SL \& Knight PG 2005 Bone morphogenetic proteins (BMP) $-4,-6$, and -7 potently suppress basal and luteinizing hormone-induced androgen production by bovine theca interna cells in primary culture: could ovarian hyperandrogenic dysfunction be caused by a defect in thecal BMP signaling? Endocrinology 146 1883-1892. (https://doi.org/10.1210/ en.2004-1303)

Glister C, Satchell L \& Knight PG 2010 Changes in expression of bone morphogenetic proteins (BMPs), their receptors and inhibin co-receptor betaglycan during bovine antral follicle development: inhibin can antagonize the suppressive effect of BMPs on thecal androgen production. Reproduction 140 699-712. (https://doi.org/10.1530/REP-10-0216)

Glister C, Satchell L \& Knight PG 2011 Granulosal and thecal expression of bone morphogenetic protein- and activin-binding protein mRNA transcripts during bovine follicle development and factors modulating their expression in vitro. Reproduction 142 581-591. (https://doi.org/10.1530/REP-11-0150)

Glister C, Satchell L, Bathgate RA, Wade JD, Dai Y, Ivell R, AnandIvell R, Rodgers RJ \& Knight PG 2013 Functional link between bone morphogenetic proteins and insulin-like peptide 3 signaling in modulating ovarian androgen production. PNAS 110 E1426-E1435. (https://doi.org/10.1073/pnas.1222216110)

Glister C, Sunderland SJ, Boland MP, Ireland JJ \& Knight PG 2015 Comparison of bioactivities, binding properties and intrafollicular 
levels of bovine follistatins. Reproduction 150 85-96. (https://doi org/10.1530/REP-15-0086)

Haugen MJ \& Johnson AL 2010 Bone morphogenetic protein 2 inhibits FSH responsiveness in hen granulosa cells. Reproduction 140 551-558. (https://doi.org/10.1530/REP-10-0211)

Hillier SG 1987 Intrafollicular paracrine function of ovarian androgen. Journal of Steroid Biochemistry 27 351-357. (https://doi.org/10.1016/ 0022-4731(87)90327-X)

Hillier SG 1991 Regulatory functions for inhibin and activin in human ovaries. Journal of Endocrinology 131 171-175. (https://doi. org/10.1677/joe.0.1310171)

Itoh S \& ten Dijke P 2007 Negative regulation of TGF-beta receptor/ Smad signal transduction. Current Opinion in Cell Biology 19 176-184. (https://doi.org/10.1016/j.ceb.2007.02.015)

Juengel JL, Reader KL, Bibby AH, Lun S, Ross I, Haydon LJ \& McNatty KP 2006 The role of bone morphogenetic proteins 2, 4, 6 and 7 during ovarian follicular development in sheep: contrast to rat. Reproduction 131 501-513. (https://doi.org/ 10.1530/rep.1.00958)

Knight PG \& Glister C 2006 TGF-beta superfamily members and ovarian follicle development. Reproduction 132 191-206. (https://doi. org/10.1530/rep.1.01074)

Lee WS, Yoon SJ, Yoon TK, Cha KY, Lee SH, Shimasaki S, Lee S \& Lee KA 2004 Effects of bone morphogenetic protein-7 (BMP-7) on primordial follicular growth in the mouse ovary. Molecular Reproduction and Development 69 159-163. (https://doi.org/10.1002/ mrd.20163)

Li X, Ionescu AM, Schwarz EM, Zhang X, Drissi H, Puzas JE, Rosier RN, Zuscik MJ \& O'Keefe RJ 2003 Smad6 is induced by BMP-2 and modulates chondrocyte differentiation. Journal of Orthopaedic Research 21 908-913. (https://doi.org/10.1016/S0736-0266(03) 00008-1)

Livak KJ \& Schmittgen TD 2001 Analysis of relative gene expression data using real-time quantitative PCR and the 2(-Delta Delta C(T)) Method. Methods 25 402-408. (https://doi.org/10.1006/ meth.2001.1262)

Miyazono K 2000 TGF-beta signaling by Smad proteins. Cytokine and Growth Factor Reviews 11 15-22. (https://doi.org/10.1016/S13596101(99)00025-8)

Mulloy B \& Rider CC 2015 The bone morphogenetic proteins and their antagonists. Vitamins and Hormones 99 63-90. (https://doi. org/10.1016/bs.vh.2015.06.004)

Nakamura T, Hasegawa Y, Sugino K, Kogawa K, Titani K \& Sugino H 1992 Follistatin inhibits activin-induced differentiation of rat follicular granulosa cells in vitro. Biochimica et Biophysica Acta 1135 103-109. (https://doi.org/10.1016/0167-4889(92)90173-9)

Nilsson EE, Larsen G \& Skinner MK 2014 Roles of Gremlin 1 and Gremlin 2 in regulating ovarian primordial to primary follicle transition. Reproduction 147 865-874. (https://doi.org/10.1530/REP14-0005)

Otsuka F, Moore RK, Iemura S, Ueno N \& Shimasaki S 2001a Follistatin inhibits the function of the oocyte-derived factor BMP-15. Biochemical and Biophysical Research Communications 289 961-966. (https://doi.org/10.1006/bbrc.2001.6103)

Otsuka F, Moore RK \& Shimasaki S 2001b Biological function and cellular mechanism of bone morphogenetic protein-6 in the ovary. Journal of Biological Chemistry 276 32889-32895. (https://doi. org/10.1074/jbc.M103212200)

Pangas SA, Jorgez CJ \& Matzuk MM 2004 Growth differentiation factor 9 regulates expression of the bone morphogenetic protein antagonist gremlin. Journal of Biological Chemistry 279 32281-32286. (https:// doi.org/10.1074/jbc.M403212200)

Pereira RC, Economides AN \& Canalis E $2000 a$ Bone morphogenetic proteins induce gremlin, a protein that limits their activity in osteoblasts. Endocrinology 141 4558-4563. (https://doi.org/10.1210/ endo.141.12.7851)

Pereira RC, Rydziel S \& Canalis E $2000 b$ Bone morphogenetic protein-4 regulates its own expression in cultured osteoblasts. Journal of Cellular Physiology 182 239-246. (https://doi. org/10.1002/(SICI)1097-4652(200002)182:2<239::AIDJCP13>3.0.CO;2-W)

Piccolo S, Agius E, Lu B, Goodman S, Dale L \& De Robertis EM 1997 Cleavage of Chordin by Xolloid metalloprotease suggests a role for proteolytic processing in the regulation of Spemann organizer activity. Cell 91 407-416. (https://doi.org/10.1016/S00928674(00)80424-9)

Pierre A, Pisselet C, Dupont J, Mandon-Pepin B, Monniaux D, Monget P \& Fabre S 2004 Molecular basis of bone morphogenetic protein-4 inhibitory action on progesterone secretion by ovine granulosa cells. Journal of Molecular Endocrinology 33 805-817. (https://doi. org/10.1677/jme.1.01545)

Pierre A, Pisselet C, Monget P, Monniaux D \& Fabre S 2005 Testing the antagonistic effect of follistatin on BMP family members in ovine granulosa cells. Reproduction Nutrition Development 45 419-425. (https://doi.org/10.1051/rnd:2005031)

Regan SL, Knight PG, Yovich JL, Stanger JD, Leung Y, Arfuso F, Dharmarajan A \& Almahbobi G 2016 Dysregulation of granulosal bone morphogenetic protein receptor $1 \mathrm{~B}$ density is associated with reduced ovarian reserve and the age-related decline in human fertility. Molecular and Cellular Endocrinology 425 84-93. (https://doi. org/10.1016/j.mce.2016.01.016)

Regan SLP, Knight PG, Yovich JL, Leung Y, Arfuso F \& Dharmarajan A 2018 Involvement of bone morphogenetic proteins (BMP) in the regulation of ovarian function. Vitamins and Hormones 107 227-261. (https://doi.org/10.1016/bs.vh.2018.01.015)

Rice S, Ojha K, Whitehead S \& Mason H 2007 Stage-specific expression of androgen receptor, follicle-stimulating hormone receptor, and anti-Mullerian hormone type II receptor in single, isolated, human preantral follicles: relevance to polycystic ovaries. Journal of Clinical Endocrinology and Metabolism 92 1034-1040. (https://doi. org/10.1210/jc.2006-1697)

Satchell L, Glister C, Bleach EC, Glencross RG, Bicknell AB, Dai Y, Anand-Ivell R, Ivell R \& Knight PG 2013 Ovarian expression of insulin-like peptide 3 (INSL3) and its receptor (RXFP2) during development of bovine antral follicles and corpora lutea and measurement of circulating INSL3 levels during synchronized estrous cycles. Endocrinology 154 1897-1906. (https://doi.org/10.1210/ en.2012-2232)

Sen A, Prizant H, Light A, Biswas A, Hayes E, Lee HJ, Barad D, Gleicher N \& Hammes SR 2014 Androgens regulate ovarian follicular development by increasing follicle stimulating hormone receptor and microRNA-125b expression. PNAS 111 3008-3013. (https://doi. org/10.1073/pnas.1318978111)

Shimasaki S, Moore RK, Otsuka F \& Erickson GF 2004 The bone morphogenetic protein system in mammalian reproduction. Endocr Rev 25 72-101. (https://doi.org/10.1210/er.2003-0007)

Souza CJ, Campbell BK, McNeilly AS \& Baird DT 2002 Effect of bone morphogenetic protein 2 (BMP2) on oestradiol and inhibin A production by sheep granulosa cells, and localization of BMP receptors in the ovary by immunohistochemistry. Reproduction 123 363-369. (https://doi.org/10.1530/rep.0.1230363)

Sudo S, Avsian-Kretchmer O, Wang LS \& Hsueh AJ 2004 Protein related to DAN and cerberus is a bone morphogenetic protein antagonist that participates in ovarian paracrine regulation. Journal of Biological Chemistry 279 23134-23141. (https://doi.org/10.1074/jbc. M402376200)

Walsh DW, Godson C, Brazil DP \& Martin F 2010 Extracellular BMPantagonist regulation in development and disease: tied up in knots. https://jme.bioscientifica.com

https://doi.org/10.1530/JME-18-0198 (c) 2019 Society for Endocrinology Published by Bioscientifica Ltd. Printed in Great Britain 
Trends in Cell Biology 20 244-256. (https://doi.org/10.1016/j. tcb.2010.01.008)

Wiater E \& Vale W 2003 Inhibin is an antagonist of bone morphogenetic protein signaling. Journal of Biological Chemistry $\mathbf{2 7 8}$ 7934-7941. (https://doi.org/10.1074/jbc.M209710200)

Wrathall JH \& Knight PG 1995 Effects of inhibin-related peptides and oestradiol on androstenedione and progesterone secretion by bovine theca cells in vitro. Journal of Endocrinology 145 491-500. (https:// doi.org/10.1677/joe.0.1450491)
Xiao S, Findlay JK \& Robertson DM 1990 The effect of bovine activin and follicle-stimulating hormone (FSH) suppressing protein/ follistatin on FSH-induced differentiation of rat granulosa cells in vitro. Molecular and Cellular Endocrinology 69 1-8. (https://doi. org/10.1016/0303-7207(90)90082-J)

Zimmerman LB, De Jesus-Escobar JM \& Harland RM 1996 The Spemann organizer signal noggin binds and inactivates bone morphogenetic protein 4. Cell 86 599-606. (https://doi.org/10.1016/S00928674(00)80133-6)

Received in final form 8 October 2018

Accepted 25 October 2018

Accepted Preprint published online 29 October 2018 